National Water-Quality Assessment Program

\title{
Estimated Annual Agricultural Pesticide Use for Counties of the Conterminous United States, 2008-12
}

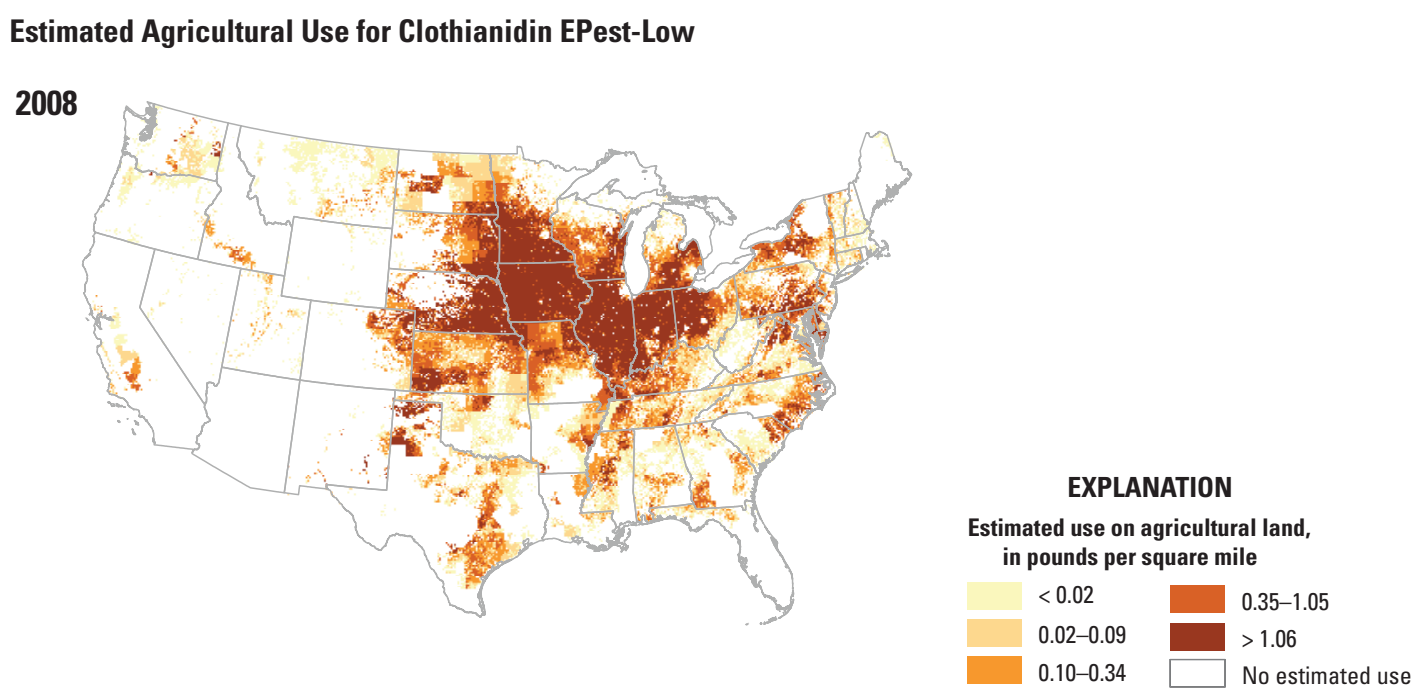

2012

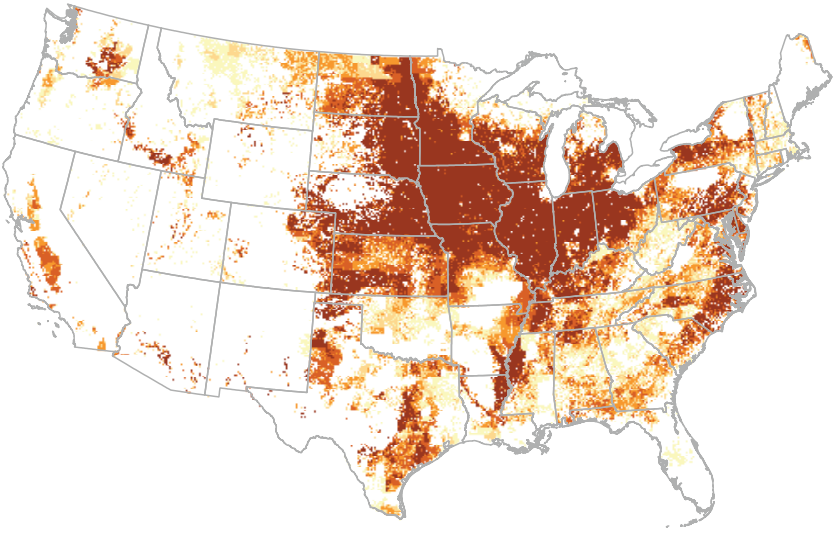

Data Series 907

U.S. Department of the Interior

U.S. Geological Survey 
Cover: Maps showing Estimated Agricultural Use for Clothianidin EPest-Low in 2008 and 2012, as an example of data within report. 


\section{Estimated Annual Agricultural Pesticide Use for Counties of the Conterminous United States, 2008-12}

By Nancy T. Baker and Wesley W. Stone

National Water-Quality Assessment Program

Data Series 907 


\title{
U.S. Department of the Interior SALLY JEWELL, Secretary
}

\section{U.S. Geological Survey Suzette M. Kimball, Acting Director}

\author{
U.S. Geological Survey, Reston, Virginia: 2015
}

For more information on the USGS - the Federal source for science about the Earth, its natural and living resources, natural hazards, and the environment, visit http://www.usgs.gov or call 1-888-ASK-USGS.

For an overview of USGS information products, including maps, imagery, and publications, visit http://www.usgs.gov/pubprod.

To order this and other USGS information products, visit http://store.usgs.gov.

Any use of trade, firm, or product names is for descriptive purposes only and does not imply endorsement by the U.S. Government.

Although this information product, for the most part, is in the public domain, it also may contain copyrighted materials as noted in the text. Permission to reproduce copyrighted items must be secured from the copyright owner.

Suggested citation:

Baker, N.T., and Stone, W.W., 2015, Estimated annual agricultural pesticide use for counties of the conterminous United States, 2008-12: U.S. Geological Survey Data Series 907, 9 p., http://dx.doi.org/10.3133/ds907.

ISSN 2327-638X (online) 


\section{Contents}

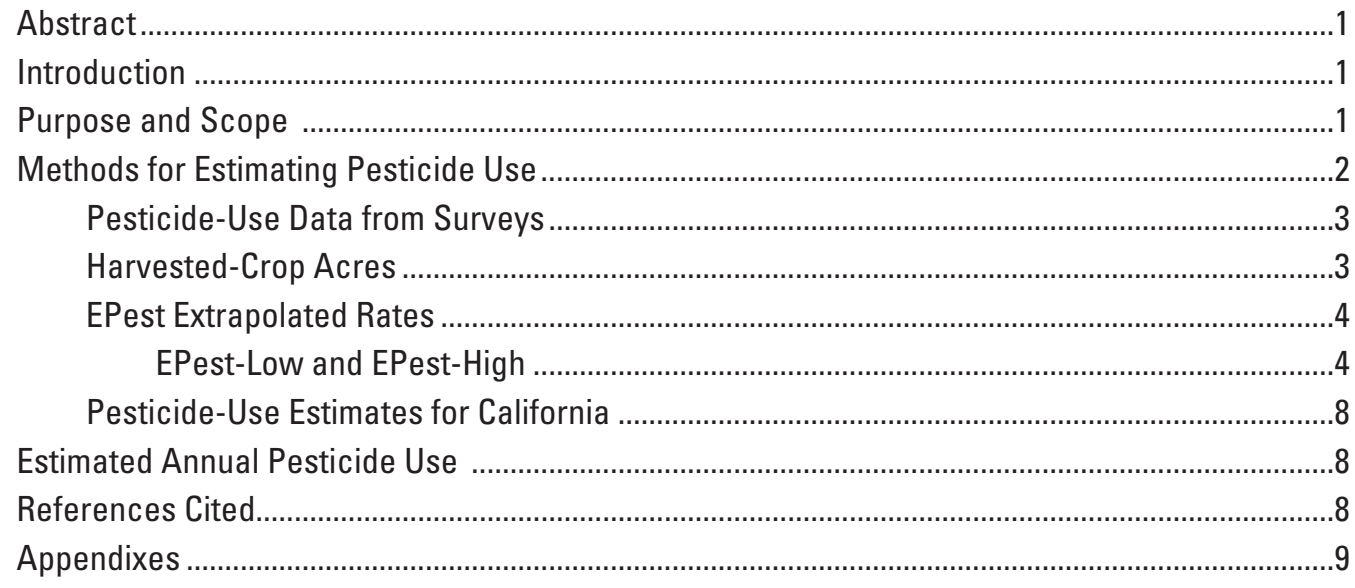

\section{Figures}

1. Map showing county boundaries and U.S. Department of Agriculture Crop Reporting Districts and Farm Resources Regions of the conterminous

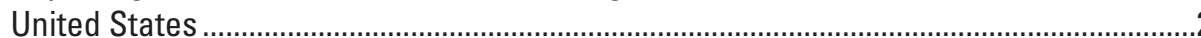

2. Graphs showing percentage of acres reported by the 2007 and 2012 Agricultural Censuses, County Agricultural Production Survey (2008-11), and acres derived from linear interpolation for each crop in the conterminous United States......................5

3. Map showing an example decision process for calculating an estimated pesticide use (EPest) rate when a Crop Reporting District (CRD) rate is not reported or is considered missing 1 1

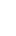
8 8 9 


\section{Conversion Factors}

Inch/pound to International System of Units

\begin{tabular}{|c|c|c|}
\hline Multiply & By & To obtain \\
\hline \multicolumn{3}{|c|}{ Area } \\
\hline acre & 4,047 & square meter $\left(\mathrm{m}^{2}\right)$ \\
\hline acre & 0.4047 & hectare (ha) \\
\hline acre & 0.4047 & square hectometer $\left(\mathrm{hm}^{2}\right)$ \\
\hline acre & 0.004047 & square kilometer $\left(\mathrm{km}^{2}\right)$ \\
\hline \multicolumn{3}{|c|}{ International System of Units to Inch/pound } \\
\hline Multiply & By & To obtain \\
\hline \multicolumn{3}{|c|}{ Mass } \\
\hline kilogram (kg) & 2.205 & pound avoirdupois (lb) \\
\hline
\end{tabular}

\section{Abbreviations}

$\begin{array}{ll}\text { Ag Census } & \text { Census of Agriculture } \\ \text { CAPS } & \text { County Agricultural Production Survey } \\ \text { CRD } & \text { Crop Reporting District } \\ \text { DPR-PUR } & \text { Department of Pesticide Regulation-Pesticide Use Reports (California) } \\ \text { EPest } & \text { estimated pesticide use } \\ \text { FIPS } & \text { Federal Information Processing Standard } \\ \text { NAWOA } & \text { National Water-Quality Assessment Program }\end{array}$




\title{
Estimated Annual Agricultural Pesticide Use for Counties of the Conterminous United States, 2008-12
}

\author{
By Nancy T. Baker and Wesley W. Stone
}

\section{Abstract}

Annual county-level pesticide use was estimated for 423 herbicides, insecticides, and fungicides applied to agricultural crops grown in the conterminous United States during 2008-12. For all States except California, pesticide-use data were compiled from proprietary surveys of farm operations located within U.S. Department of Agriculture Crop Reporting Districts (CRDs). Surveyed pesticide-use data were used in conjunction with county annual harvested-crop acres reported by the U.S. Department of Agriculture 2007 and 2012 Censuses of Agriculture and the 2008-11 County Agricultural Production Survey to calculate use rates per harvested-crop acre, or an "estimated pesticide use" (EPest) rate, for each crop by year. County-use estimates were then calculated by multiplying EPest rates by harvested-crop acres for each pesticide crop combination. Use estimates for California were obtained from annual Department of Pesticide Regulation-Pesticide Use Reports.

Proprietary surveyed pesticide-use data were not available for all CRDs and years. When pesticide-survey data were unavailable for a CRD in a particular year, EPest extrapolated rates were calculated from adjoining or nearby CRDs to ensure that pesticide use was estimated for all counties where harvested-crop acres were reported. Two estimation methods were used-EPest-low and EPest-high — and differed in how they treated situations when a CRD was surveyed and pesticide use was not reported for a particular pesticide-bycrop combination. California pesticide-use estimates were not extrapolated; therefore, EPest-low and EPest-high are the same for counties in California.

This data series is a continuation of the 1992-2009 pesticide-use estimates reported by Stone (2013). It is an update of estimates for 2008-9 (Stone, 2013), as well as an update of the 2010-11 preliminary estimates reported by Baker and Stone (2013). EPest values from these compilations (1992-2012) are suitable for making national, regional, and watershed assessments of annual pesticide use. County-level estimates are provided to make it easier to compile watershed assessments; however, users should be aware there is a greater degree of uncertainty in individual county-level estimates when compared to CRD or State-level estimates. This report provides
EPest-low and EPest-high annual agricultural pesticide use for counties of the conterminous United States for 423 compounds during 2008-12 in tab-delimited files organized by compound, year, State Federal Information Processing Standard (FIPS) code, county FIPS code, and amount in kilograms (kg).

\section{Introduction}

The U.S. Geological Survey National Water-Quality Assessment (NAWQA) Program, which began in 1991, conducts national-scale assessments of the occurrence and trends of pesticides in streams and groundwater of the United States. Direct measurement of pesticide concentrations in all of the Nation's streams and aquifers would be ideal but the high cost of monitoring and analysis makes this not possible. Therefore, statistical models and other types of models are developed and used for predicting water-quality conditions for streams and groundwater that are not sufficiently monitored. Pesticide-use estimates are crucial predictive components of these models.

In addition, understanding changes in stream and groundwater pesticide concentrations over time (trend analysis) requires annual pesticide-use estimates that are compiled and developed with consistent methods. Annual county-level pesticide-use estimates have been used in conjunction with long-term pesticide trend analysis in streams (Ryberg and others, 2014) and groundwater (Toccalino and others, 2014).

\section{Purpose and Scope}

The purpose of this report is to provide estimated annual pesticide use, referred to as EPest-low and EPest-high, for 423 pesticides for each county in the conterminous United States. Methods used to compile EPest-low and EPest-high also are provided. This data series is a continuation of the 1992-2009 pesticide-use estimates reported by Stone (2013). It is an update of estimates for 2008-9 (Stone, 2013), as well as an update of the 2010-11 preliminary estimates reported by Baker and Stone (2013). Estimates of annual agricultural pesticide use are provided via this report as downloadable, 
tab-delimited files, which are organized by compound, year, State Federal Information Processing Standard (FIPS) code, county FIPS code, and amounts in kilograms $(\mathrm{kg})$.

\section{Methods for Estimating Pesticide Use}

For all States except California, pesticide-use data compiled by proprietary surveys of farm operations located within U.S. Department of Agriculture Crop Reporting Districts (CRDs) - a collection of contiguous counties within each
State (fig. 1) - were used in conjunction with county annual harvested-crop acres reported by the U.S. Department of Agriculture (2009, 2014), 2007 and 2012 Censuses of Agriculture (Ag Census); and 2008-11 County Agricultural Production Survey (CAPS), (U.S. Department of Agriculture-National Agricultural Statistics Service, Various years) to calculate use rates per harvested-crop acre, or an 'estimated pesticide use' (EPest) rate, for each crop by year. County-use estimates were then calculated by multiplying EPest rates by harvested-crop acres for each pesticide crop combination. The methods documented in this report follow methods developed by Thelin and Stone (2013).

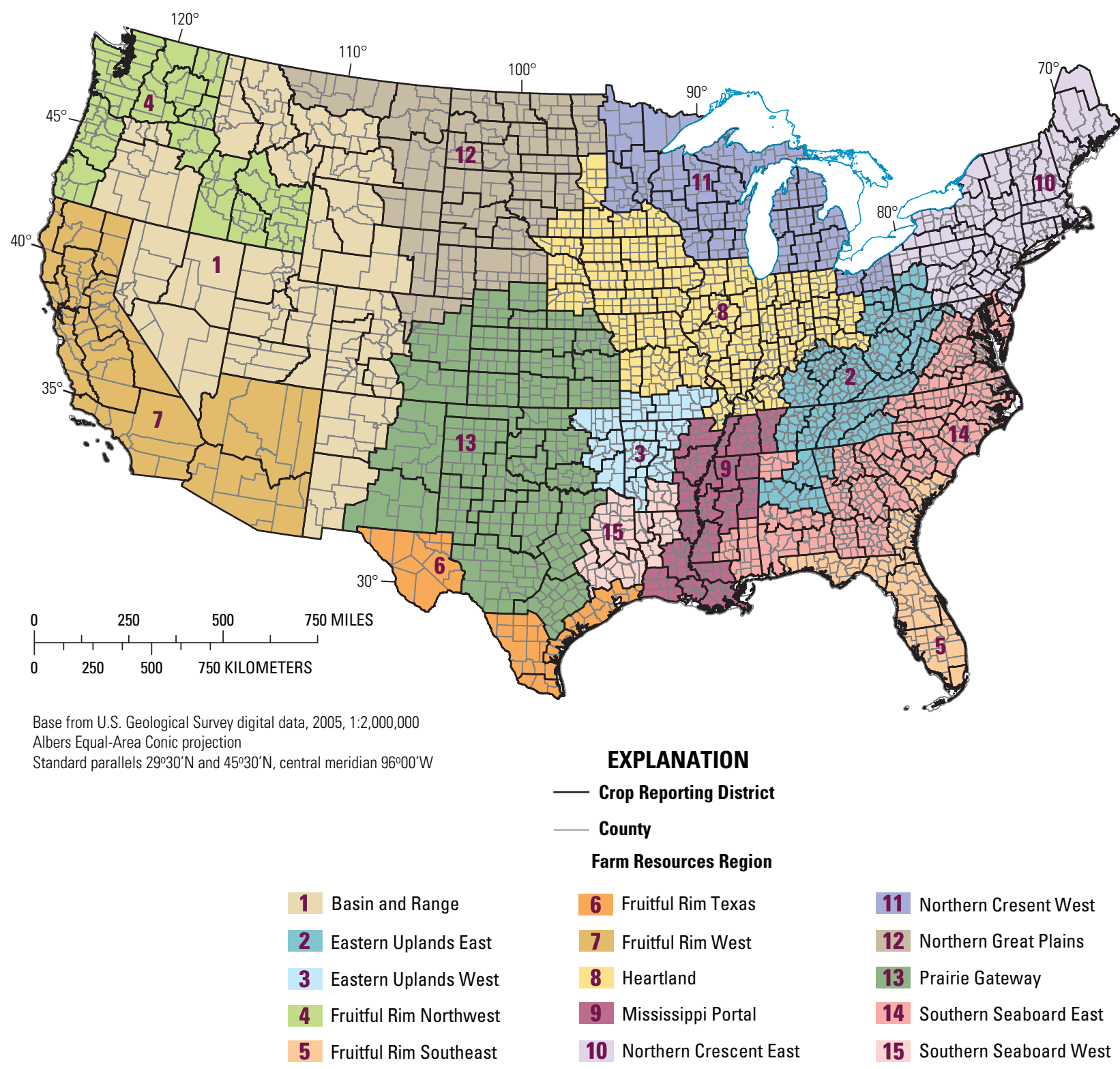

Figure 1. County boundaries and U.S. Department of Agriculture Crop Reporting Districts and Farm Resources Regions of the conterminous United States. 
Pesticide-survey data were not available for all CRDs and years. When data were unavailable for a CRD in a particular year, EPest extrapolated rates were calculated from adjoining or nearby CRDs to ensure that pesticide use was estimated for all counties within CRDs where harvested-crop acres were reported. Pesticide-survey data and EPest extrapolated rates are based on harvested-crop acres within a CRD, but many NAWQA modeling applications and analyses require pesticide-use estimates at the county scale. Therefore, EPest was disaggregated from CRDs to the individual counties and estimates were then calculated by multiplying EPest rates by annual county harvested-crop acres for each pesticide crop combination. EPest extrapolated rate determination and subsequent application to county harvested-crop acres differs between EPest-low and EPest-high methods. Use estimates for California were obtained from annual Department of Pesticide Regulation-Pesticide Use Reports (DPR-PUR) and used without extrapolation; therefore, EPest-low and EPest-high are the same for counties in California.

\section{Pesticide-Use Data from Surveys}

Methods for obtaining surveyed pesticide-use data for this compilation are the same as for the 1992-2009 compilation (Stone, 2013). Survey methods reported by Thelin and Stone (2013) are reiterated here for context in this (2008-12) compilation-method description.

Proprietary data from GfK Kynetec, Inc., on the amounts of pesticides applied to individual crops by CRDs are the primary source of information used in this study and are referred to as "pesticide-survey" data in the remainder of this report. The pesticide-survey data are based on agricultural pesticideuse surveys of more than 20,000 farm operations distributed throughout the conterminous United States (GfK Kynetec, AgroTrak Quality Management Plan, written commun., August 2011). Data from the Ag Census on the size (in acres) and number of farms that grow individual crops and represent selected land uses, such as pasture, are used to stratify all farms in the United States by size and to allocate the number of farms that will be surveyed in each strata. The survey design allocates a greater proportion of the sample to larger farm operations so that a greater percentage of crop acres are represented, with the goal of more accurate characterization of farm operations and pesticide-use patterns. Surveys of farm operations within each CRD are extrapolated to represent total pesticide use for that CRD. The likelihood of underestimating or overestimating use for less widely used pesticides increases because not all farms within a CRD are surveyed. Use estimates for 423 pesticides that are applied to a variety of row, specialty, fruit, and nut crops are reported by multi-county areas, referred to as CRDs. The CRD to county geospatial relation is shown in figure 1. All surveyed pesticides and crops included in this compilation are listed in appendix 1, tables 1-1 through 1-3.

\section{Harvested-Crop Acres}

County annual harvested-crop acres reported in the 2007 and $2012 \mathrm{Ag}$ Census (U.S. Department of Agriculture, 2009, 2014) and 2008-11 CAPS (U.S. Department of AgricultureNational Agricultural Statistics Service, Various years) were used in this compilation. The Ag Census is the most uniform and complete source of crop-acre estimates for all counties in the United States. The Ag Census is published every 5th year with CAPS reporting crop-acre estimates for selected crops and counties for interim Ag Census years.

Both Ag Census and CAPS report data for planted- and harvested-crop acres, but planted acres are only available for a limited number of crops and are not always available for all crops that are contained in the pesticide-survey data. Therefore, harvested acres, rather than planted acres, were used to develop annual pesticide-by-crop use rates. In taking this approach, it is recognized that use-rate estimates could be numerically greater than actual use rates on planted crops because not all planted acres are harvested. Annual harvestedcrop acres by county data were used to calculate the pesticideby-crop use rates for each crop and CRD surveyed, and to estimate pesticide use for all counties that report harvested acres in the conterminous United States.

A list of the 58 crops for which EPest use rates were developed and the Ag Census and CAPS crop names for which acres data were obtained is given in table $1-1$. For some crops, it was necessary to combine subcategories of $\mathrm{Ag}$ Census and CAPS acres to match pesticide-survey data. For example, $\mathrm{Ag}$ Census reports harvested acres for "BLACKBERRIES AND DEWBERRIES (INCLUDING MARIONBERRIES)," "BOYSENBERRIES," "LOGANBERRIES," and "RASPBERRIES, ALL," while the pesticide-survey data contain the crop category "Caneberries." In this instance, Ag Census harvestedcrop acres were summed to better match the pesticide-survey data. Conversely, the pesticide-survey data contain the crop categories "Grapes, Raisin," "Grapes, Table," and "Grapes, Wine," while Ag Census reports only "GRAPES." In this case, pesticide-survey data were summed to match the Ag Census report. $\mathrm{Ag}$ Census crop acres that were combined to match pesticide-survey data are given in table 1-1.

In some cases, when a small number of farms within a county produce a crop, Ag Census and CAPS do not report county acres for that particular crop because of census nondisclosure rules that protect the identity of individual farm operations. Both Ag Census and CAPS include the nondisclosed county crop acres in State total acres. To estimate county crop acres in these cases, total reported county crop acres for each State were subtracted from total reported State crop acres to determine the number of nondisclosed crop acres for each State. To allocate those acres back to "nondisclosed" counties, crop acres were proportioned to individual counties based on the proportion of total agricultural land within each county. The proportion of total agricultural land within each county was determined from the 2011 National Land Cover Data (Jin and others, 2013). 
CAPS data are used to supply crop-acre estimates for non-census years because Ag Census data are available only every 5 th year. CAPS are conducted in 44 States for selected crops (http://www.nass.usda.gov/Surveys/Guide_to_NASS Surveys/County_Agricultural_Production). Crops selected for county surveys are specific to each State and may change from year to year. Crops included in CAPS are primarily field crops such as barley, corn, cotton, and rice. Only a few vegetables and no fruit crops are included in CAPS (all CAPS crops are listed in table 1-1).

CAPS do not include acres for every crop/county/year combination used in this compilation; therefore, linear interpolation was used to fill gaps where county harvested crop acres were missing. Interpolation was done for each individual crop prior to combining subcategories of crops for every county.

For many crops, CAPS data were not available for any county for the inter-Ag Census period (2008-11), and crop acres were interpolated entirely from $\mathrm{Ag}$ Census data. For crops where CAPS data were available, interpolation was done on those counties with missing data. The percentage of acres derived from interpolation for each crop is shown in figure 2. Interpolation is done for each county and crop before crops are combined into categories. For a small number of counties and crops, harvested acres were missing (indicated with a blankzero acres are indicated with a dash in Ag Census data) in either the 2007 or $2012 \mathrm{Ag}$ Census. When this was the case, Ag Census acres for the missing data were interpolated from either U.S. Department of Agriculture-National Agricultural Statistics Service acres or the remaining available Ag Census value resulting in a small percentage of interpolated acres for Ag Census (see Caneberries graph in fig. 2). It is recognized that interpolation may overestimate or underestimate crop acres, especially in areas of the country where CAPS data are limited.

\section{EPest Extrapolated Rates}

The following section describes methods developed by Thelin and Stone (2013) to estimate agricultural pesticide use for counties in the conterminous United States - except those in California - that were in unsurveyed CRDs but where crops were grown and pesticide use was likely. For all surveyed CRDs, pesticide-by-crop use rates were calculated from either surveyed pesticide use divided by surveyed crop acres, or surveyed pesticide use divided by Ag Census or CAPS crop acres. When a CRD was surveyed but harvested-crop acres from Ag Census and CAPS were greater than the surveyed crop acres, rates were calculated from the surveyed pesticide use and the total Ag Census and CAPS harvested acres for the CRD. For unsurveyed CRDs, EPest extrapolated rates were developed by using surveyed rates from nearby CRDs or from surveyed and extrapolated rates from CRDs in the same U.S. Department of Agriculture Farm Resources Region (fig. 1). A surveyed rate or an extrapolated rate, depending on the CRD, was then applied to county harvested acres to estimate pesticide use on individual crops grown in each county.
To ensure that pesticide-use estimates accounted for all acreage that could have been treated, extrapolated use rates were developed for individual pesticides and crops in unsurveyed CRDs through a set of decision rules that depend on the availability of rates from surrounding CRDs (Thelin and Stone, 2013). The decision process included developing three types of extrapolated pesticide-by-crop use rates, referred to as tier 1, tier 2, and regional rates. Tier 1 CRDs are any contiguous $\mathrm{CRD}$ surrounding the unsurveyed $\mathrm{CRD}$ regardless of whether the tier 1 CRD is within the same Farm Resourc Regions(fig. 3). Tier 1 CRDs surrounding the unsurveyed CRD were searched, and if one or more surveyed pesticideby-crop use rate existed, the median rate was used from these surveyed rates to estimate pesticide-by-crop use for the counties in the unsurveyed CRD. If a tier 1 rate could not be established because there were no surveyed rates available, then tier 2 CRDs were searched to determine if three or more of the tier 2 CRDs had surveyed rates (fig. 3). If so, then the median value of these rates was applied to the unsurveyed CRD. Finally, if a tier 1 or tier 2 EPest rate could not be determined, then a regional rate was calculated for the Farm Resources Region and applied to county crop acres within the CRD. Regional rates were the median of all non-zero EPest rates, including surveyed, tier 1, and tier 2 EPest from the same Farm Resources Region. It is important to understand that the process is iterative, so that for each unsurveyed CRD within a region, tier 1 rates are calculated first, then tier 2 rates, regardless of whether the CRD is within the Farm Resources Region. After the tier 1 and tier 2 rates have been established, a regional rate is calculated. Duplicate extrapolated rates were removed prior to the calculation to reduce the influence of duplicate extrapolated EPest rates on the calculation of regional rates because the same CRD may be used to calculate tier 2 rates within a region.

\section{EPest-Low and EPest-High}

Two variations on the previously described method were developed to yield EPest-low and EPest-high for counties in the conterminous United States other than California (Thelin and Stone, 2013) because uncertainties are inherent in the EPest extrapolation. Calculating two values allows the user to select the method that best suits the application for which these estimates are used. Both methods incorporated surveyed and extrapolated rates to estimate pesticide use for counties, but EPest-low and EPest-high estimations differed in how they treated situations when a CRD was surveyed and pesticide use was not reported for a particular pesticide-by-crop combination. If use of a pesticide on a crop was not reported in a surveyed CRD, EPest-low reports zero use in the CRD for that pesticide-by-crop combination. EPest-high, however, treats the unreported use for that pesticide-by-crop combination in the CRD as unsurveyed, and pesticide-by-crop use rates from neighboring CRDs and, in some cases, CRDs within the same Farm Resources Region are used to calculate the pesticide-bycrop EPest-high rate for the CRD. 

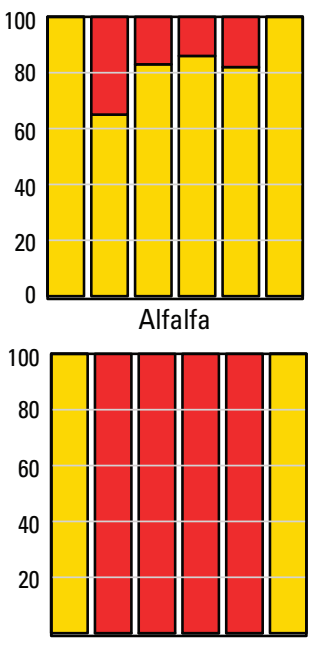

Asparagus

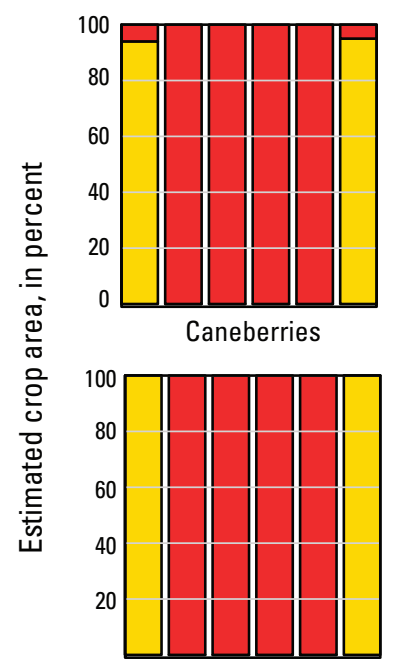

Celery

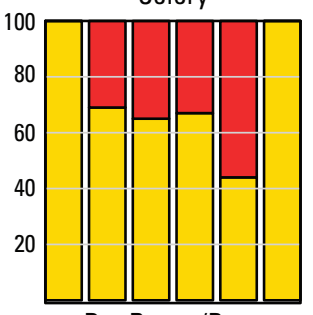

Dry Beans/Peas

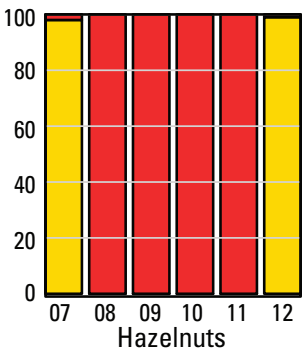

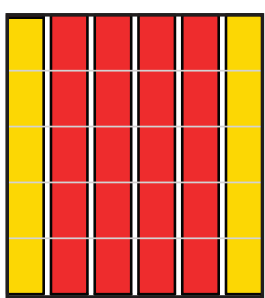

Almonds

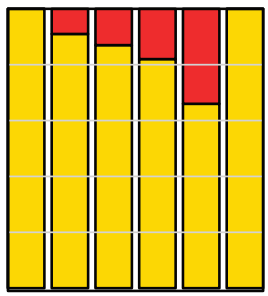

Barley

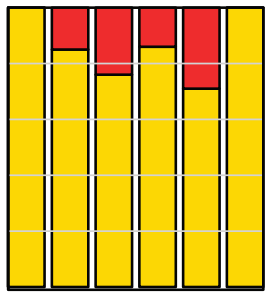

Canola (oilseed rape)

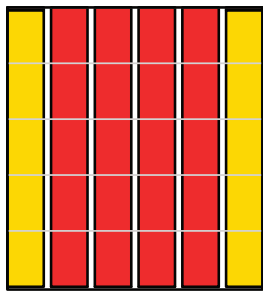

Cherries

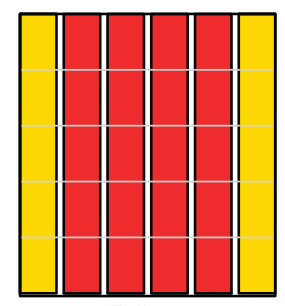

Fallow

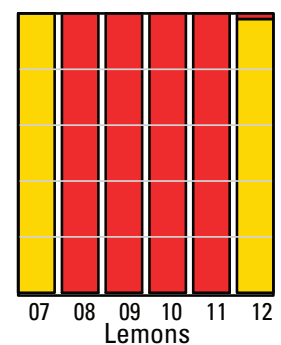

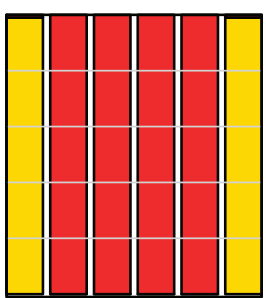

Apples

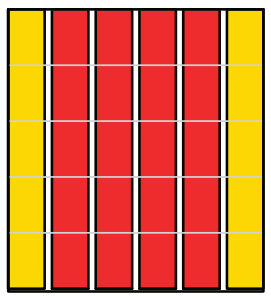

Beans (Snap, Bush, Pole, String)

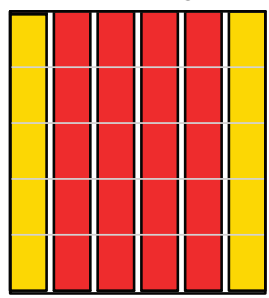

Cantaloupes

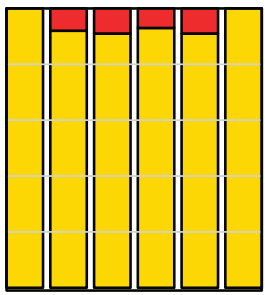

Corn

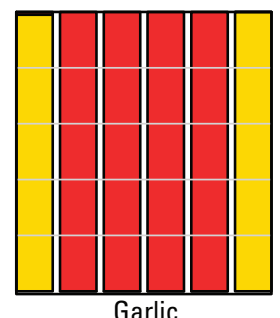

Garlic

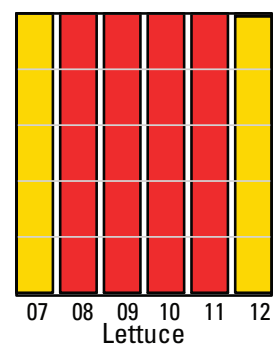

EXPLANATION

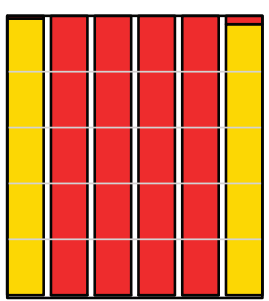

Apricots

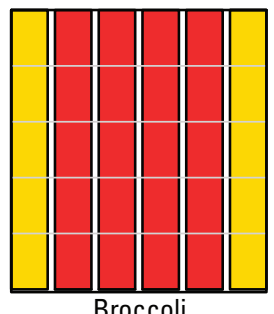

Broccoli

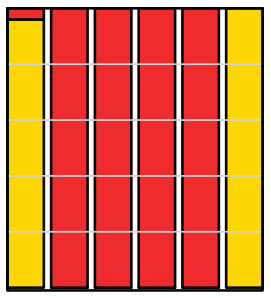

Carrots

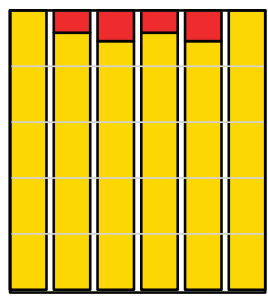

Cotton

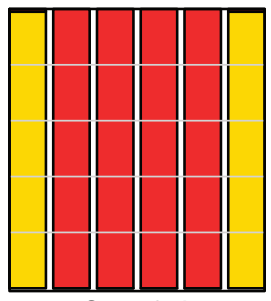

Grapefruit

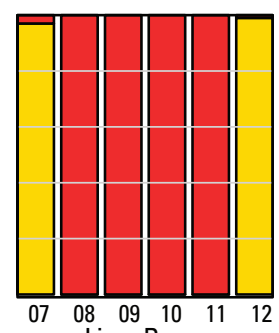

Lima Beans

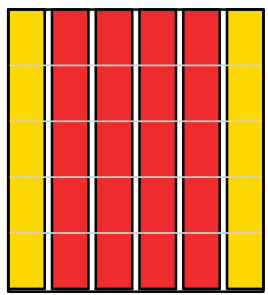

Artichoke

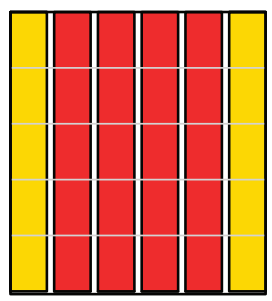

Cabbage

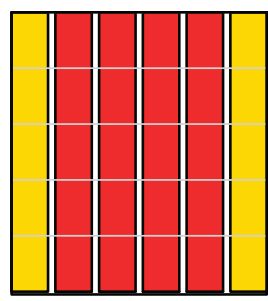

Cauliflower

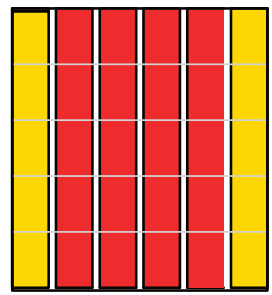

Cucumbers

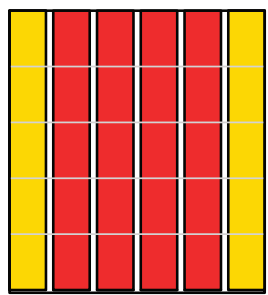

Grapes

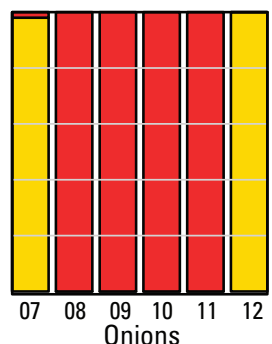

Reported acres $\square$ Interpolated acres

Figure 2. Percentage of acres reported by the 2007 and 2012 Agricultural Censuses (U.S. Department of Agriculture, 2009, 2014), County Agricultural Production Survey (2008-11), and acres derived from linear interpolation for each crop in the conterminous United States. 

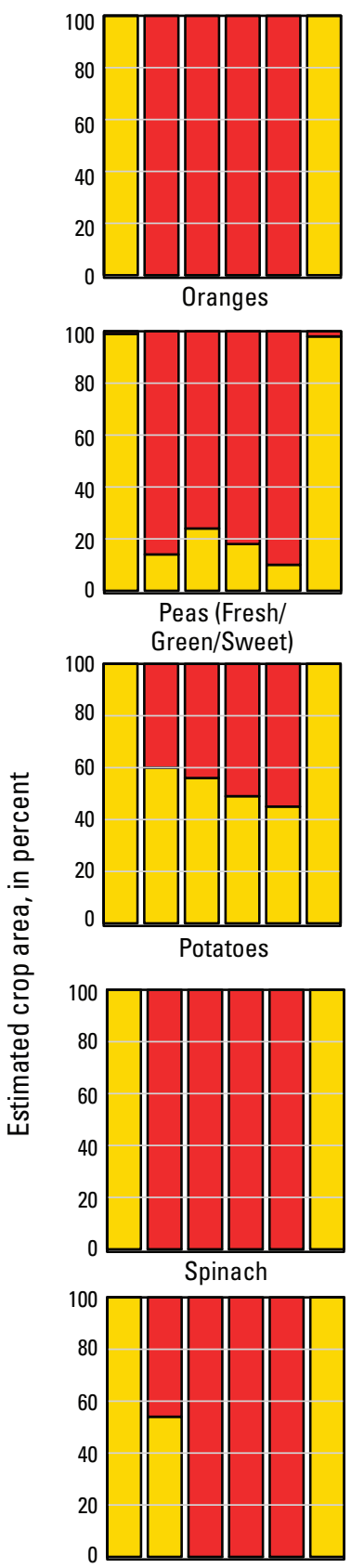

Sunflowers

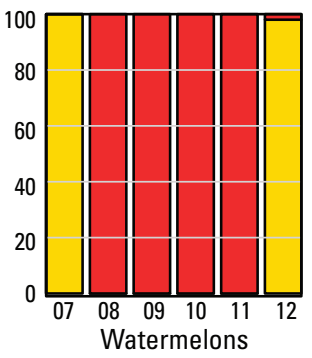

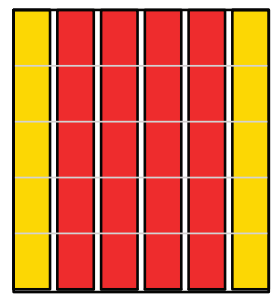

Pastureland

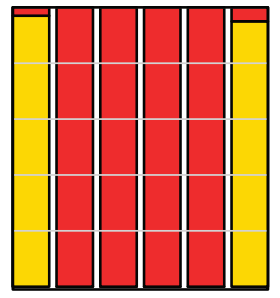

Pecans

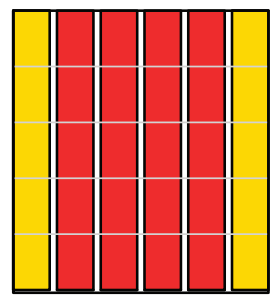

Pumpkins

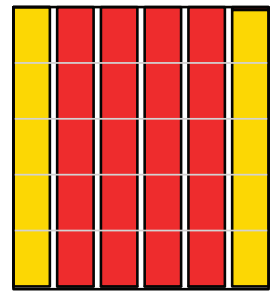

Squash

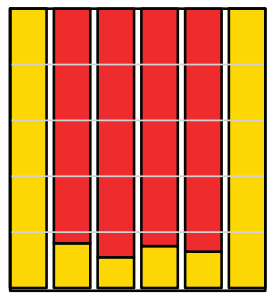

Sweet Corn

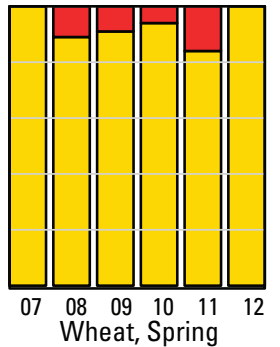

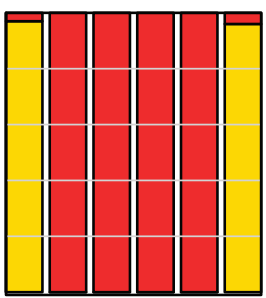

Peaches

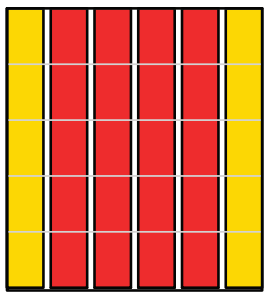

Peppers

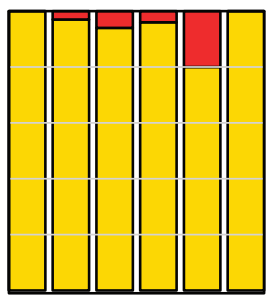

Rice

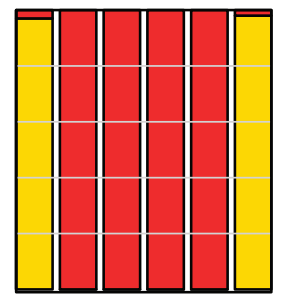

Strawberries

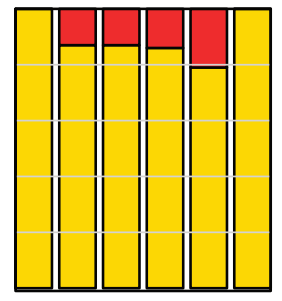

Tobacco

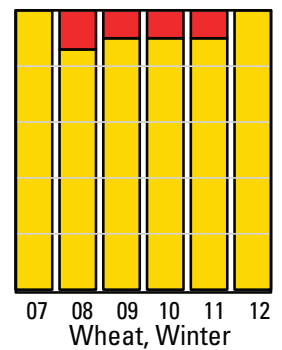

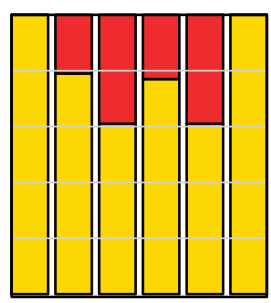

Peanuts

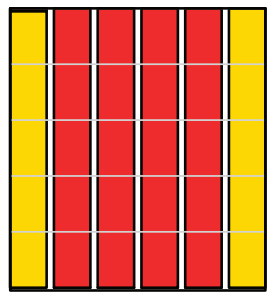

Pistachios

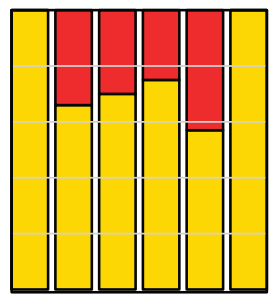

Sorghum (Milo)

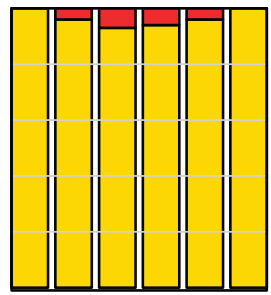

Sugar Beets

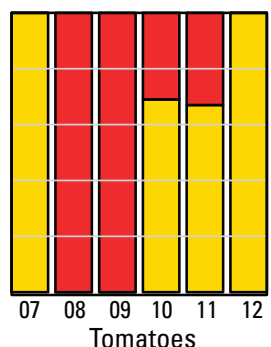

Tomatoes

\section{EXPLANATION}

Reported acres

Interpolated acres

Figure 2. Percentage of acres reported by the 2007 and 2012 Agricultural Censuses (U.S. Department of Agriculture, 2009, 2014), County Agricultural Production Survey (2008-11), and acres derived from linear interpolation for each crop in the conterminous United States.-Continued 


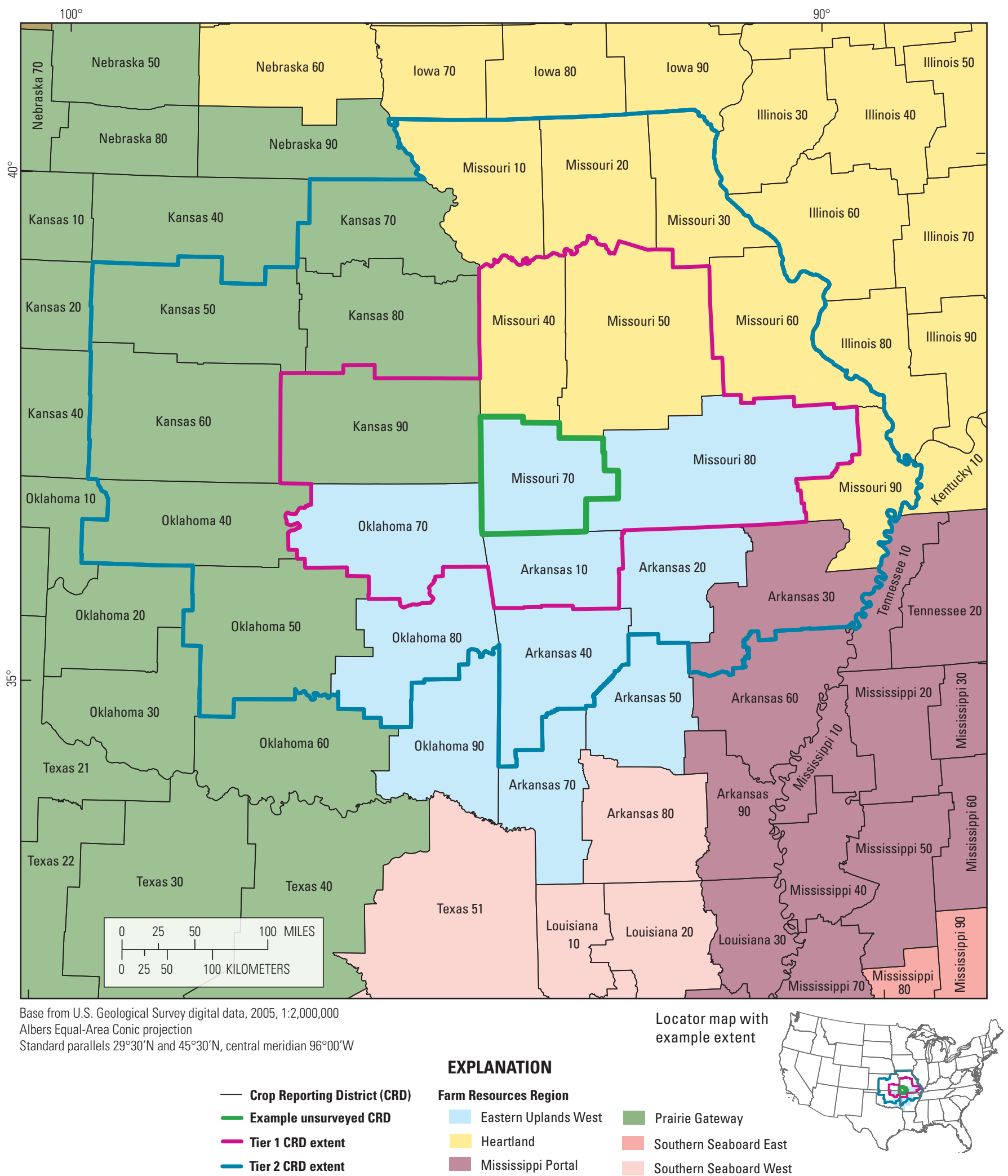

Figure 3. An example decision process for calculating an estimated pesticide use (EPest) rate when a Crop Reporting District (CRD) rate is not reported or is considered missing. In this example, a surveyed rate for Missouri 70 was not reported; therefore, surveyed rates for all tier 1 CRDs (median) were used to calculate a rate for the unsurveyed CRD. If there are no surveyed tier 1 rates available for Missouri 70, then available surveyed rates for all tier 2 CRDs (median) are evaluated. When neither tier 1 nor tier 2 rates are available, regional rates a calculated from all unique surveyed tier 1 and tier 2 CRD rates (median) within a Farm Resources Region. 


\section{Pesticide-Use Estimates for California}

EPest-low and EPest-high estimates for California were not calculated using the method described in the previous section; instead, county totals were obtained from the online DPR-PUR database (California Department of Pesticide Regulation, 2014). Since 1990, California has required reporting of all agricultural pesticide use. DPR-PUR includes information on the pesticide applied, location and time of application, and the agricultural crop treated. Annual pesticide-use estimates by crop were retrieved from the online DPR-PUR database and merged with the EPest-low and EPest-high county data after the estimation process was completed for the rest of the country. A list of the 117 crops for which agricultural pesticide-use data were available is given in table 1-2. EPest-low and EPest-high estimates for counties in California are the same because California data were not extrapolated. Estimates are included in both EPest-low and EPest-high data tables to facilitate ease of use.

\section{Estimated Annual Pesticide Use}

EPest-low and EPest-high annual agricultural pesticide use for counties of the conterminous United States for 423 compounds during 2008-12 are provided in tab-delimited files organized by compound, year, State FIPS code, county FIPS code, and $\mathrm{kg}$. Data files are available in appendix 2, tables 2-1 through 2-14. This data series is a continuation of the 19922009 pesticide-use estimates reported by Stone (2013). It is an update of Stone's reported estimates for 2008-9, as well as an update of the 2010-11 preliminary estimates reported by Baker and Stone (2013).

EPest values from this study are suitable for making national, regional, and watershed assessments of annual pesticide use during 2008-12. Although estimates are provided by county to facilitate estimation of watershed pesticide use for a wide variety of watersheds, there is a greater degree of uncertainty in individual county-level estimates when compared to CRDs or State-level estimates because (1) EPest crop-use rates were developed on the basis of pesticide use on harvested acres in multi-county areas (CRDs) and then allocated to county harvested cropland; (2) pesticide-by-crop use rates were not available for all CRDs in the conterminous United States, and extrapolation methods were used to estimate pesticide use for those counties; and (3) it is possible that surveyed pesticide-by-crop use rates do not reflect all agricultural use on all crops grown.

\section{References Cited}

Baker, N.T., and Stone, W.W., 2013, Preliminary estimates of annual agricultural pesticide use for counties of the conterminous United States, 2010-11: U.S. Geological Survey OpenFile Report 2013-1295, 2-p. pamphlet, 14 tables, http://pubs. usgs.gov/of/2013/1295/.

California Department of Pesticide Regulation, Various years, Pesticide use reporting (PUR): Sacramento, Calif., Department of Pesticide Regulation, accessed April 2014 at http:/www.cdpr.ca.gov/docs/pur/purmain.htm.

Jin, S., Yang, L., Danielson, P., Homer, C., Fry, J., and Xian, G., 2013, A comprehensive change detection method for updating the National Land Cover Database to circa 2011: Remote Sensing of Environment, v. 132, p. 159-175, accessed April 2014 at http://www.mrlc.gov/nlcd2011.php.

Ryberg, K.R., Vecchia, A.V., Gilliom, R.J., and Martin, J.D., 2014, Pesticide trends in major rivers of the United States, 1992-2010: U.S. Geological Survey Scientific Investigations Report 2014-5135, 63 p., http://pubs.usgs.gov/ sir/2014/5135/.

Stone, W.W., 2013, Estimated annual agricultural pesticide use for counties of the conterminous United States, 1992-2009: U.S. Geological Survey Data Series 752, 1-p. pamphlet, 14 tables, http://pubs.usgs.gov/ds/752/.

Thelin, G.P., and Stone, W.W., 2013, Estimation of annual agricultural pesticide use for counties of the conterminous United States, 1992-2009: U.S. Geological Survey Scientific Investigations Report 2013-5009, 54 p., http://pubs.usgs.gov/ $\operatorname{sir} / 2013 / 5009 /$.

Toccalino, P.L., Gilliom, R.J., Lindsey, B.D., and Rupert, M.G., 2014, Pesticides in groundwater of the United StatesDecadal-scale changes, 1993-2011: Groundwater, v. 52, p. 112-125, http://pubs.er.usgs.gov/publication/70127095.

U.S. Department of Agriculture, 2009, 2007 Census of Agriculture, State and County Data, Volume 1, Geographic Area Series Part 1-50, AC-07-A-1-AC-07-A-50: Washington D.C., U.S. Department of Agriculture, National Agricultural Statistics Service, accessed May 2013 at http://www.agcensus.usda.gov/Publications/2007/.

U.S. Department of Agriculture, 2014, 2012 Census of Agriculture, State and County Data, Volume 1, Geographic Area Series Part 1-50, AC-12-A-1-AC-12-A-50: Washington D.C., U.S. Department of Agriculture, National Agricultural Statistics Service, accessed May 2013 at http://www.agcensus.usda.gov/Publications/2012/.

U.S. Department of Agriculture-National Agricultural Statistics Service, Various years, Quick-Stats-Field crops: Washington D.C., U.S. Department of Agriculture, accessed May 2014 at http://www.nass.usda.gov/Quick_Stats/. 


\section{Appendixes}

Appendixes are available online at: http://dx.doi.org/10.3133/ds0907.

Appendix 1. List of Crops and Pesticides for Which Estimates Were Made

1-1. Crops for which proprietary surveyed pesticide-use data were provided to U.S. Geological Survey for EPest compilation and matching Agricultural Census and County Agricultural Survey Program crop names.

1-2. Crops for which California Department of Pesticide Regulation-Pesticide Use Reports were used for EPest compilation.

1-3. Pesticides for which proprietary surveyed pesticide-use data were provided to U.S. Geological Survey for EPest compilation.

Appendix 2. EPest-Low and EPest-High Use Estimates

EPest-high county pesticide-use estimates, by pesticide name:

2-1. 2, 4-D through Chlorantraniliprole

2-2. Chlorethoxyfos through Diflufenzopyr

2-3. Dimethenamid through Gibberellic acid

2-4. Glufosinate through Metiram

2-5. Metolachlor through Propazine

2-6. Propiconazole through Triasulfuron

2-7. Tribenuron methyl through Zoxamide

EPest-Iow county pesticide-use estimates, by pesticide name:

2-8. 2, 4-D through Chlorantraniliprole

2-9. Chlorethoxyfos through Diflufenzopyr

2-10. Dimethenamid through Gibberellic acid

2-11. Glufosinate through Metiram

2-12. Metolachlor through Propazine

2-13. Propiconazole through Triasulfuron

2-14. Tribenuron methyl through Zoxamide 




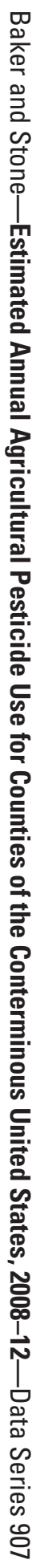

